\title{
Comparison of IgG Fc receptors from clinical isolates of Streptococcus zooepidemicus
}

\author{
M. YARNALL and P.R. WIDDERS
}

\begin{abstract}
Department of Veterinary Microbiology and Pathology, Washington State University, Pullman, Washington 99164-7040, USA
\end{abstract}

\begin{abstract}
Summary. A receptor binding the Fc region of equine immunoglobulin G (IgG) has been isolated from a heat-extracted preparation of a clinical isolate of Streptococcus zooepidemicus. This $\mathrm{Fc}$ receptor has a $\mathrm{M}_{\mathrm{r}}$ of $45 \times 10^{3}$ and was occasionally seen as an apparent trimer of $M_{r} 130 \times 10^{3}$. Antibodies prepared in horses against the receptor could be adsorbed to and eluted from whole live bacteria, confirming the surface location of this protein. Another 11 isolates of $S$. zooepidemicus from horses with pneumonia, abscesses or endometritis were tested for Fc-receptor activity. Although the $\mathrm{M}_{\mathrm{r}}$ of the $\mathrm{Fc}$ receptors varied among isolates, their antigenicity was conserved. Thus, the Fc receptor is an attractive candidate for application in the diagnosis of, or protection against, infections with $S$. zooepidemicus.
\end{abstract}

\section{Introduction}

Streptococcus zooepidemicus is the most common bacterial species causing endometritis in mares (Bain, 1966; Shin et al., 1979; Ricketts, 1981; Wingfield Digby and Ricketts, 1982) and is the primary aetiological agent in $15-20 \%$ of equine abortions (Roberts, 1971; Welsh, 1984). This level of reproductive wastage in the mare may be minimised through application of specific immunological techniques for protecting against streptococcal infections in the equine reproductive tract. Effective immunological protection requires that the immune response be directed to surface antigens that are conserved among the majority of pathogenic isolates of $S$. zooepidemicus.

$S$. zooepidemicus possesses a surface Fc receptor which is distinct from those of other streptococci (Myhre and Kronvall, 1982) and from protein A of Staphylococcus aureus (Myhre and Kronvall, 1981). The aim of this study was to investigate antigenic conservation among the $\mathrm{Fc}$ receptors of clinical isolates of $S$. zooepidemicus. In this paper we describe the isolation of a $S$. zooepidemicus $F c$ receptor, demonstrate its immunogenicity, and characterise its antigenic homology with receptors from other isolates of $S$. zooepidemicus.

\section{Materials and methods}

\section{Bacteria and growth conditions}

Twelve isolates of $S$. zooepidemicus were isolated from

Received 26 May 1988; accepted 25 July 1988. horses with clinical conditions that included endometritis (7 cases), pneumonia (2), a cutaneous wound and abscesses (2). Isolates were stored at $-70^{\circ} \mathrm{C}$ in glycerol $60 \% \mathrm{v} / \mathrm{v}$ in $0.1 \mathrm{M}$ phosphate-buffered saline (PBS) $\mathrm{pH} 7 \cdot 2$. Bacteria were plated on Blood Agar (Difco Laboratories, Detroit, MI, USA) and cultured overnight. The entire growth was resuspended in $2 \mathrm{ml}$ of Todd-Hewitt Broth (Difco) and $0.5 \mathrm{ml}$ was transferred to $50 \mathrm{ml}$ of broth and cultured overnight in a shaking water bath $\left(37^{\circ} \mathrm{C}\right.$, $150 \mathrm{rpm})$. Bacteria, harvested by centrifugation $(10000 \mathrm{~g}$, $10 \mathrm{~min}$ ) were resuspended in $0.25 \mathrm{M}$ Tris- $\mathrm{HCl}(\mathrm{pH} \mathrm{6.8)}$. S. zooepidemicus isolate no. 1381 , isolated from a case of equine endometritis, was used in most experiments.

\section{Heat-extracted preparations}

Harvested bacteria were heated at $90^{\circ} \mathrm{C}$ for $10 \mathrm{~min}$ and, after centrifugation at $10000 \mathrm{~g}$ for $10 \mathrm{~min}$, the supernate, which contained a relatively pure preparation of $\mathrm{Fc}$ receptor, was dialysed against distilled water.

Sodium dodecyl sulphate-polyacrylamide gel electrophoresis (SDS-PAGE) and Western blotting

Bacterial suspensions $\left(c .5 \times 10^{8}\right.$ bacteria/ml $)$ in $0.25 \mathrm{M}$ Tris-HCl (pH 6.8), or heated extracts, were mixed in a ratio of $2: 1(\mathrm{v}: \mathrm{v})$ with sample buffer (SDS $6 \% \mathrm{w} / \mathrm{v}$, glycerol $40 \% \mathrm{v} / \mathrm{v}, 2$-mercaptoethanol $7 \% \mathrm{v} / \mathrm{v}$ in $0.5 \mathrm{M}$ Tris$\mathrm{HCl} \mathrm{pH} \mathrm{6.8)}$ and boiled for $3 \mathrm{~min}$. Samples were electrophoresed as described by Laemmli (1970). Separated proteins were electroblotted on to nitrocellulose (Towbin et al., 1979) and allowed to react with equine IgG-Fc fragments, $F\left(a b^{\prime}\right)_{2}$ fragments or antisera, followed by peroxidase-conjugated anti-equine IgG (Kirkegaard and Perry, Gaithersburg, MD, USA). Blots were developed with chloronaphthol $0.3 \% \mathrm{w} / \mathrm{v}$ in methanol 
$20 \mathrm{ml}$, mixed with hydrogen peroxide $0.018 \% \mathrm{w} / \mathrm{v}$ and $0.5 \mathrm{M}$ sodium chloride in $0.02 \mathrm{M}$ Tris- $\mathrm{HCl}$ ( $\mathrm{pH} 7.5$ ).

Blots were then stained for proteins with amido black $0.1 \% \mathrm{w} / \mathrm{v}$ in isopropanol:acetic acid:water $(25: 10: 65)$ and destained with methanol:acetic acid: water $(40: 10: 50)$.

\section{Isolation of Fc receptor}

Heat-extracted preparation of $S$. zooepidemicus no. 1381 was electrophoresed on SDS-polyacrylamide gel with reducing conditions and stained with Coomassie blue. The protein band of $M_{r} 45 \times 10^{3}$ was cut from the gel, eluted with a unidirectional electroelutor (model UEA, International Biotechnologies Incorporated New Haven, CT, USA), dialysed against distilled water and concentrated by lyophilisation.

\section{Equine sera}

Heat-killed bacteria (c. $2 \times 10^{9}$ cells) of $S$. zooepidemicus strain no. 1219 were injected into a horse by the intramuscular (i.m.) route. Serum was collected before immunisation and 2 and 6 weeks after immunisation and stored at $-20^{\circ} \mathrm{C}$ in divided portions.

Monospecific polyclonal antibodies against the $\mathrm{Fc}$ receptor of $S$. zooepidemicus strain no. 1381 were prepared by immunising horses with the antigen of $M_{r} 45 \times 10^{3}$, electroeluted from SDS-polyacrylamide gels; $10-\mu \mathrm{g}$ amounts of electroeluted protein in muramyl-dipeptide adjuvant $250 \mu \mathrm{g} / \mathrm{ml}$ were given by two i.m. injections 4 weeks apart. Serum was collected 2 weeks after the last injection.

\section{Affinity-purified IgG and IgG-fragments}

Antiserum specific for the $\mathrm{Fc}$ receptor $\left(\mathrm{M}_{\mathrm{r}} 45 \times 10^{3}\right)$ was affinity-purified by adsorption to and elution from $S$. zooepidemicus strain no. 1381. Antiserum $(25 \mathrm{ml})$ was incubated for $2 \mathrm{~h}$ at $20^{\circ} \mathrm{C}$ with $S$. zooepidemicus ( $5 \mathrm{~g}$ wet wt). Bacteria were centrifuged ( $10000 \mathrm{~g}$ for $10 \mathrm{~min})$ and resuspended in $10 \mathrm{ml}$ of $0.1 \mathrm{M}$ glycine- $\mathrm{HCl}$ buffer $(\mathrm{pH}$ $2 \cdot 2$ ). The supernate recovered after centrifugation was neutralised by the addition of Trizma base (Sigma Chemical Co., St Louis, MO, USA) and dialysed against $10 \mathrm{mM}$ Tris- $\mathrm{HCl}$ (pH 6.8).

$\mathrm{F}\left(\mathrm{ab}^{\prime}\right)_{2}$ fragments of the above affinity-purified antiserum made against the protein of $M_{r} 45 \times 10^{3}$ were prepared by pepsin digestion as described before (Yarnall et al., 1988). IgG was incubated in $0.1 \mathrm{M}$ sodium acetate (pH 4.2) with pepsin (Sigma) $5 \% \mathrm{w} / \mathrm{w}$ for $8 \mathrm{~h}$ at $37^{\circ} \mathrm{C}$. More pepsin was added after $8 \mathrm{~h}$ and incubation continued for a further $16 \mathrm{~h}$ at $37^{\circ} \mathrm{C}$. $\mathrm{F}\left(\mathrm{ab}^{\prime}\right)_{2}$ fragments were harvested after absorption of undigested IgG with protein A-sepharose (Pierce Chemical Co., Rockford, IL, USA).

Polyspecific equine IgG was digested with papain and the Fc fragments isolated by ion-exchange chromatography on DEAE-cellulose (Widders et al., 1988). Purity of Ig-fragment preparations was monitored by SDS-PAGE.

\section{Results}

\section{Isolation of Fc receptor}

Nitrocellulose blots of whole-cell and heatextracted preparations of $S$. zooepidemicus strain no. 1381 were probed with equine $F c$ fragments to identify the Fc receptor. A protein of $M_{r} 45 \times 10^{3}$ reacted with $\mathrm{Fc}$ fragments in both antigen preparations of $S$. zooepidemicus (fig. 1, lanes 1 and 2). In heat-extracted preparations, another protein of $\mathrm{M}_{\mathrm{r}}$ $130 \times 10^{3}$ was also reactive (fig. 1, lane 2). When the protein of $M_{r} 45 \times 10^{3}$ was isolated by electroelution, subjected to SDS-PAGE and probed with Fc fragments, it retained $F c$ receptor activity (fig. 1, lane 3). When, however, the protein of $M_{r} 130 \times$ $10^{3}$ was electroeluted and subjected to SDS-PAGE, it migrated as a protein of $M_{r} 45 \times 10^{3}$ (data not shown).

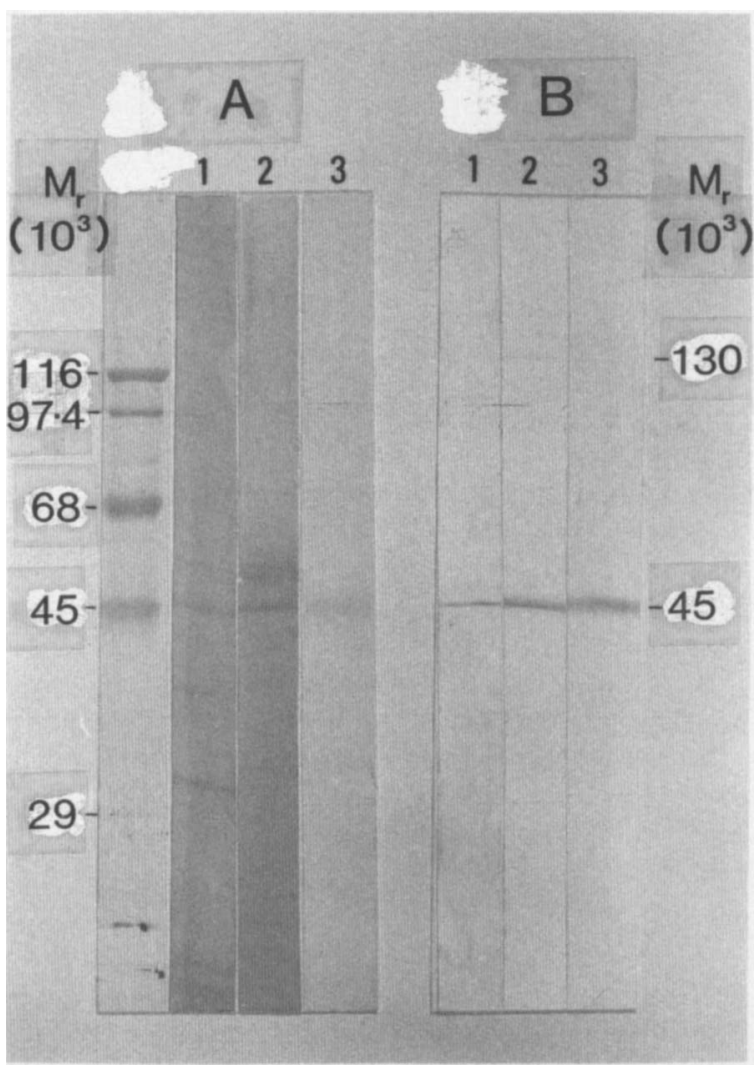

Fig. 1. Identification of $F c$ receptor of $S$. zooepidemicus strain no. 1381. Proteins, after SDS-PAGE and electroblotting to nitrocellulose were: stained with amido black, panel $A$; or probed with equine $\mathrm{Fc}(40 \mu \mathrm{g} / \mathrm{ml})$ followed by peroxidaseconjugated goat anti-horse IgG diluted 1 in 1000 . Lane 1whole-cell preparation; lane 2-heat-extracted preparation; lane 3-electroeluted $\mathrm{Fc}$ receptor, $M_{r} 45 \times 10^{3}$. $M_{r}$ indicates marker proteins. 
Reactivity of the Fc receptor with $S$. zooepidemicus antiserum

Samples of whole-cell and heat-extracted preparations of $S$. zooepidemicus strain no. 1381 were electrophoresed by SDS-PAGE, electroblotted on to nitrocellulose, and probed with pre- and postimmunisation antisera raised against $S$. zooepidemicus. At a dilution of 1 in 20000 , immune serum reacted with $>15$ proteins in whole-cell preparations of $S$. zooepidemicus, but with $<10$ proteins in the heat-extracted preparation. Immune serum reacted strongly with a protein of $M_{r} 45 \times$ $10^{3}$ present in both preparations (fig. 2).

To avoid reactivity of the antibody via the Fc region of the molecule, $F\left(a b^{\prime}\right)_{2}$ fragments of preand post-immunisation antisera prepared against the protein of $M_{r} 45 \times 10^{3}$ were used to probe bacterial antigens transferred to nitrocellulose. Both bacterial proteins of $\mathrm{M}_{\mathrm{r}}\left(10^{3}\right) 45$ and 130 were

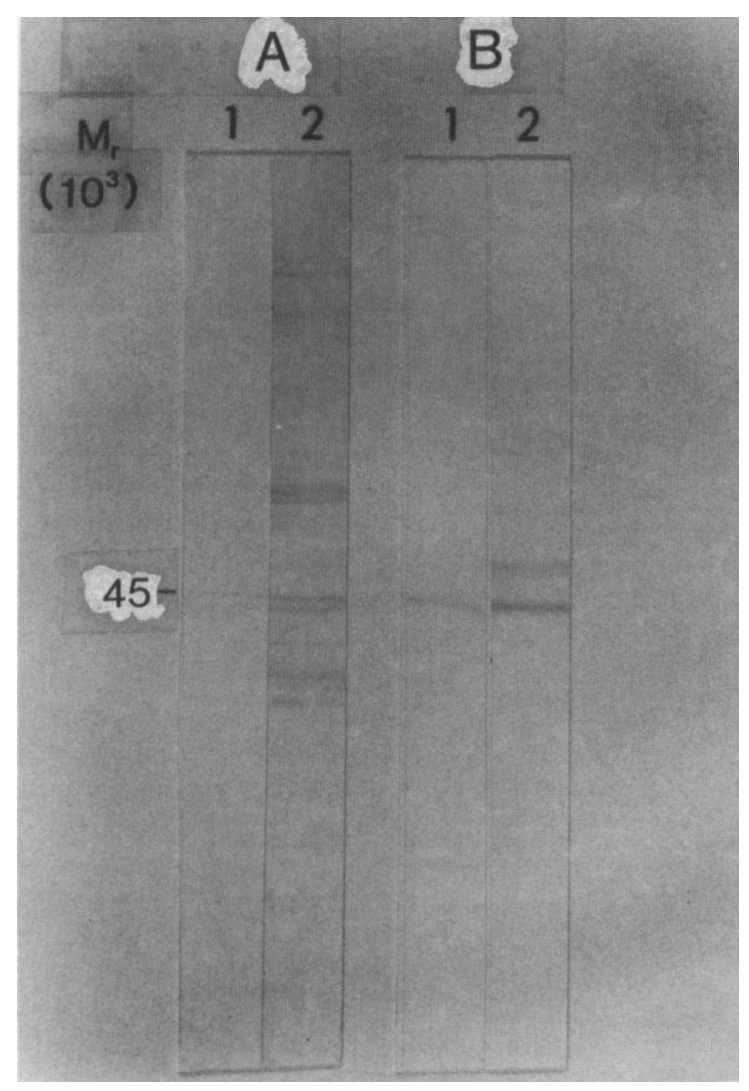

Fig. 2. Proteins in whole-cell preparations (panel A) or heatextracted preparations (panel B) of $S$. zooepidemicus strain no. 1381 probed with equine antiserum against $S$. zooepidemicus strain no. 1219 and detected with peroxidase-conjugated goat anti-horse IgG diluted 1 in 1000 . Sera were tested at a dilution of 1 in 20000 ; lane 1 -pre-immunisation; lane 2-postimmunisation. recognised by immune but not pre-immune $F\left(a b^{\prime}\right)_{2}$ fragments $(0.1 \mu \mathrm{g} / \mathrm{ml})$ in blots of whole-cell preparations of strain no. 1381 (data not shown).

\section{Antigenic conservation of Fc receptors from clinical isolates of $S$. zooepidemicus}

Heat-extracted preparations from 12 isolates from horses with pneumonia, abscesses or endometritis, were electrophoresed by SDS-PAGE, blotted on to nitrocellulose and probed with equine Fc fragments $(40 \mu \mathrm{g} / \mathrm{ml})$ or with $\mathrm{F}\left(\mathrm{ab}^{\prime}\right)_{2}$ fragments $(1 \mu \mathrm{g} / \mathrm{ml})$ of affinity-purified antiserum prepared against the protein of $M_{r} 45 \times 10^{3}$. All isolates had proteins reacting with the Fc fragments, although the $M_{r}$ of these $F c$ receptors varied among isolates (fig. 3, panel A). The $F\left(\mathrm{ab}^{\prime}\right)_{2}$-antibody preparation reacted with the $\mathrm{Fc}$ receptors of all isolates (fig. 3, panel B).

\section{Discussion}

In this study, we have isolated a surface protein from $S$. zooepidemicus that reacts with the Fc portion of equine $\mathrm{IgG}$. Although many proteins were demonstrated in the protein profile of $S$. zooepidemicus strain no. 1381 , only a few were strongly reactive with antiserum from a horse immunised with a different isolate (strain no. 1219) of $S$. zooepidemicus. This limited reactivity may reflect either poor immunogenicity of many bacterial antigens, or limited conservation of antigens among different isolates. One antigen apparently shared is the Fc receptor of $M_{r} 45 \times 10^{3}$. As reported before (Myhre and Kronvall, 1982; Reis et al., 1988), the Fc receptor is present on the surface of the bacterium. That observation was confirmed in the present study because antibody specific for the Fc receptor $\left(M_{r} 45 \times 10^{3}\right)$ could be affinity purified by adsorption to and elution from live $S$. zooepidemicus.

Antigenic conservation among the Fc receptors of clinical isolates of $S$. zooepidemicus was indicated by the reactivity of the antiserum to the protein of $\mathrm{M}_{\mathrm{r}} 45 \times 10^{3}$. Despite the considerable heterogeneity among isolates in the $M_{r}$ of proteins with $\mathrm{Fc}$ receptor activity, binding of equine $\mathrm{Fc}$ fragment was paralleled by binding of the $\mathrm{F}\left(\mathrm{ab}^{\prime}\right)_{2}$ antibody preparation. Binding of this $\mathrm{F}\left(\mathrm{ab}^{\prime}\right)_{2}$ preparation was antigen specific, because the $F\left(a b^{\prime}\right)_{2}$ preparation of preimmunisation serum did not react with the protein of $\mathrm{M}_{\mathrm{r}} 45 \times 10^{3}$ at a comparable dilution (data not shown). $F\left(a b^{\prime}\right)_{2}$ fragments were used to probe blots at a concentration one-fortieth of that of $\mathrm{Fc}$ fragments, indicating that any contaminating 


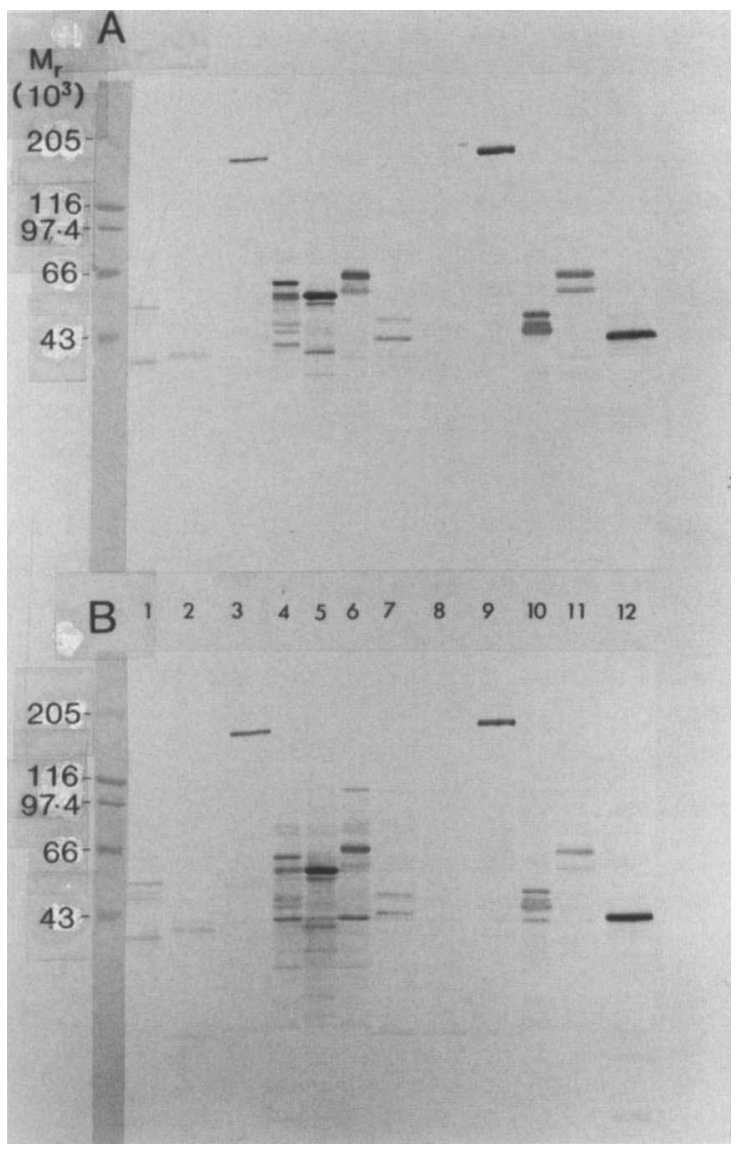

Fig. 3. Heat-extracted preparations of 12 clinical isolate of $S$. zooepidemicus, after SDS-PAGE and electroblotting to nitrocellulose, were probed with: equine Fc fragments, $40 \mu \mathrm{g} / \mathrm{ml}$, panel $A$; or $F\left(a b^{\prime}\right)_{2}$ fragments, $1 \mu \mathrm{g} / \mathrm{ml}$, against the protein of $M_{r} 45 \times$ $10^{3}$, panel B. Blots were developed as described in fig. 1 . Isolates were : lane 1, no. 10837 from cutaneous wound; lane 2, no. 10217 from abscess; lane 3, no. 8527 from abscess; lane 4, no. 7243 from pneumonia; lane 5, no. 2049 from endometritis; lane 6, no. 1854 from endometritis; lane 7, no. 1731 from endometritis; lane 8, no. 1219 from endometritis; lane 9, no. 1849 from endometritis; lane 10, no. 1826 from endometritis; lane 11 , no. 6747 from pneumonia; lane 12, no. 1381 from endometritis.

whole IgG molecules present in the $\mathrm{F}\left(\mathrm{ab}^{\prime}\right)_{2}$ preparation, undetectable by SDS-PAGE, could not account for the binding observed with this preparation.

\section{REFERENCES}

Bain A M 1966 The role of infection in infertility in the thoroughbred mare. Theriogenology 21 : 168-173.

Christensen P, Johansson B G, Kronvall G 1976 Interaction of streptococci with the Fc fragment of IgG. Acta Pathologica et Microbiologica Scandinavica 84: 73-76.
Conservation of antigenic epitopes among streptococcal Fc receptors is predicted by the immunoglubulin-binding characteristics of these proteins. Streptococcal Fc receptors recognise a limited domain in the Fc region of IgG (Christensen et al., 1976; Schroder et al., 1987), suggesting that the structure and, therefore, antigenicity of the binding site of the bacterial Fc receptors is conserved. Although the present results confirm that antigenicity is conserved, it is not known if the antibody against the protein of $M_{r} 45 \times 10^{3}$ reacts with the specific binding site of the $\mathrm{Fc}$ receptor.

The role of the streptococcal Fc receptor in bacterial virulence is uncertain, but comparable receptor molecules in other gram-positive pathogens have been associated with enhanced virulence. In group-A streptococci, the $\mathbf{M}$ protein binds fibrinogen (Whitnack et al., 1984) and thereby restricts complement deposition on the bacterial cell surface (Whitnack and Beachey, 1982), probably by masking surface antigens. In the absence of specific antibody, this mechanism limits phagocytosis in vitro (Whitnack and Beachey, 1982) and may enhance bacterial survival in vivo by limiting effective opsonisation. Of particular significance is the antiphagocytic effect of the staphylococcal Fc receptor, protein A (Dossett et al., 1969; Peterson et al., 1977). This receptor activity limits phagocytosis either by reducing effective opsonisation (Stahlenheim et al., 1973; Peterson et al., 1977; Schalen et al., 1985) or by competing with the phagocyte $F c$ receptor for binding to the $F c$ region of specific antibody (Dossett et al., 1969; Stahlenheim et al., 1973). Staphylococci are killed after internalisation by phagocytic cells (White and Walker, 1981). Evasion of phagocytosis, therefore, will enhance bacterial survival in vivo. Antibody specific for these receptor molecules may modify their receptor function and, therefore, may enhance clearance of these organisms by host defences. On the basis of the surface location of the protein of $M_{\mathrm{r}} 45 \times 10^{3}$, its immunogenicity, and its conservation among clinical isolates, the Fc receptor of $S$. zooepidemicus is an attractive candidate in both protection against, and rapid diagnosis of, infections by $S$. zooepidemicus.

Dossett J H, Kronvall G, Williams R C, Quie P G 1969 Antiphagocytic effects of staphylococcal protein A. Journal of Immunology 103 : 1405-1410.

Laemmli U K 1970 Cleavage of structural proteins during the assembly of the head of bacteriophage T4. Nature 227:680 685.

Myhre E B, Kronvall G 1982 Demonstration of a new type of 
immunoglobulin G receptor in Streptococcus zooepidemicus strains. Infection and Immunity 27: 808-816.

Myhre E B, Kronvall G 1981 Immunoglubulin specifications of defined types of streptococcal Ig receptors. In: Holm S E, Christensen P (eds) Basic concepts of streptococci and streptococcal diseases. Reedbooks Ltd, Chertsey, Surrey, pp 209-210.

Peterson P K, Nerhoef J, Sabath L D, Quie P G 1977 Effect of protein $\mathrm{A}$ on staphylococcal opsonization. Infection and Immunity 15: 760-764.

Reis K J, Sicen E J, Boyle M D P 1988 Selective colony blotting to expand bacterial surface receptors: applications to receptors for rat immunoglobulins. Biotechniques 6: 130136.

Ricketts S W 1981 Bacteriological examinations of the mare's cervix : techniques and interpretation of results. Veterinary Record 108: 46-51.

Roberts S J 1971 Veterinary obstetrics and genital diseases (Theriogenology) 2nd edn. Ithaca, New York, pp 135-136.

Schalen C, Truedsson L, Christensen K K, Christensen P 1985 Blocking of antibody complement-dependent effector functions by streptococcal IgG Fc-receptor and staphylococcal protein A. Acta Pathologica, Microbiologica et Immunologica Scandinavica 93B : 395-400.

Schroder A K, Nardella F A, Mannik M, Johansson P J H, Christensen $P 1987$ Identification of the site on IgG Fc for interaction with streptococci of groups $A, C$ and $F$. Immunology 62: 523-527.

Shin S J, Lein D H, Aronson A L, Nusbaum S R 1979 The bacteriological culture of equine uterine contents, in-vitro sensitivity of organisms isolated and interpretation. Journal of Reproduction and Fertility Suppl 27 : 307-315.
Stahlenheim G, Götze O, Cooper N R, Sjoquist J, MullerEberhard H J 1973 Consumption of human complement components of complexes of IgG with protein A of Staphylococcus aureus. Immunochemistry 10: 501-507.

Towbin H, Staehelin T, Gordon J 1979 Electrophoretic transfer of proteins from polyacrylamide gels to nitrocellulose sheets: procedure and some applications. Proceedings of the National Academy of Science of the USA 76: 4350-4354.

Welsh R D 1984 The significance of Streptococcus zooepidemicus in the horse. Equine Practice 6: 6-16.

White A G, Walker S M 1981 A new assay for the assessment of staphylococcal killing by human leucocytes. Journal of Immunological Methods 42: 203-212.

Whitnack E, Beachey E H 1982 Antiopsonic activity of fibrinogen bound to $M$ protein on the surface of group $A$ streptococci. Journal of Clinical Investigation 69: 1042-1045.

Whitnack E, Dale J B, Beachey E H 1984 Common protective antigens of group A streptococcal $\mathbf{M}$ proteins masked by fibrinogen. Journal of Experimental Medicine 159: 12011212.

Widders P R, Smith J W, Yarnall M, McGuire T C, Corbeil L B 1988 Non-immune immunoglobulin binding by Haemophilus somnus. Journal of Medical Microbiology 26: 307-311.

Wingfield Digby N. J, Ricketts S W 1982 Results of concurrent bacteriological and cytological examinations of the endometrium of mares in routine stud farm practice 1978-1981. Journal of Reproduction and Fertility Suppl 32: 181-185.

Yarnall M, Widders P R, Corbeil L B 1988 Isolation and characterization of Fc receptors from Haemophilus somnus. Scandinavian Journal of Immunology 28 : 129-137. 